\title{
The Characterization of Dipeptidases from Escherichia coli
}

\author{
By J. W. PAYNE \\ Microbiological Research Establishment, Porton, Salisbury, Wiltshire
}

(Accepted for publication 27 January 1972)

\begin{abstract}
SUMMARY
The supernatant extracts from disrupted Escherichia coli had only low hydrolytic activity towards diglycine, divaline and prolylglycine, but latent peptidases were activated by $\mathrm{Co}^{2+}$ or $\mathrm{Mn}^{2+}$. The cations $\mathrm{K}^{+}, \mathrm{Mg}^{2+}, \mathrm{Zn}^{2+}, \mathrm{Fe}^{2+}, \mathrm{Ni}^{2+}, \mathrm{Cu}^{2+}, \mathrm{Ca}^{2+}$ and $\mathrm{Cd}^{2+}$ caused no increase in peptidase activity while $\mathrm{Cd}^{2+}, \mathrm{Zn}^{2+}$ and $\mathrm{Cu}^{2+}$ antagonized the effects of $\mathrm{Co}^{2+}$ and $\mathrm{Mn}^{2+}$. Measurements of optimum cation concentration, of $\mathrm{pH}$ optimum and of effects of various buffers led to the conclusion that the main peptidase activity towards these three peptides, and towards a broad spectrum of other dipeptides, resided in a single $\mathrm{Co}^{2+}$ activated enzyme. The activity of this peptidase was enhanced by phosphate and inhibited by veronal. Similar measurements with $\mathrm{Mn}^{2+}$ suggested the presence of several enzymes with lower activities and narrower substrate specificity than the $\mathrm{Co}^{2+}$ activated peptidase. Procedures were devised for the assay, under optimum conditions, of the main peptidase activities of a crude extract.
\end{abstract}

\section{INTRODUCTION}

Various amino acid auxotrophs of Escherichia coli can utilize peptides as sources of their required amino acids (Payne, I97 I $a, b$; Payne \& Gilvarg, 197I ; Sussman \& Gilvarg, 197I). The transport and intracellular concentration of a peptide appears not to be a rate-limiting step in its utilization and, in general, the auxotrophic growth rate on a peptide equals that obtained with the free amino acid. However, low levels of intracellular peptidase activity can lead to negligible growth rates on certain peptide substrates (Stone, 1953; Payne, 197 (b). Furthermore, the ability of certain peptides to reach high internal concentrations as a consequence of low peptidase activity can lead to inhibition of growth and even death in certain cases (Simmonds, Tatum \& Fruton, 1947; Simmonds, Harris \& Fruton, 195I; Payne, 1968; Simmonds, I970; Sussman \& Gilvarg, 1970).

The effect of a peptide on a bacterium is related to the physiological condition of the organism, which in turn reflects an apparent variation in peptidase activity in response to changes in culture conditions and phase of growth (Kogoma \& Nishi, 1965; Nishi \& Hirose, 1966; Simmonds \& Toye, 1967; Simmonds, 1970; Sussman \& Gilvarg, 1971). This paper describes the general characteristics of the main peptidase activities found in extracts of Escherichia coli, towards three structurally dissimilar dipeptides; it forms the first part of a study of the effects of environmental conditions on bacterial peptidases.

\section{METHODS}

Chemicals: Di- and triglycine were purchased from British Drug Houses Ltd, Poole, Dorset. All other peptides were obtained from Cyclo Chemical Corporation, through Baxter Laboratories, Thetford, Norfolk. Trinitrobenzene sulphonate (TNBS) was purchased from Sigma (London) Chemical Co. Ltd, London, S.W.6. 


\section{Table I. The effect of cations on the peptidase activity of crude extracts towards diglycine}

The incubation mixtures ( $\mathrm{I} \mathrm{ml}$ ) contained diglycine $(7.5 \mathrm{~mm}$ ) and either potassium phosphate $\mathrm{pH} 7.5$ (20 mM) or tris- $\mathrm{HCl}$ pH 7.9 (20 mM); crude extract was added to give approximately $15 \mu \mathrm{g}$ protein $/ \mathrm{ml}$ with $\mathrm{Co}^{2+}$ (upper part of Table), $75 \mu \mathrm{g}$ protein $/ \mathrm{ml}$ with $\mathrm{Mn}^{2+}$ (lower part of Table), and amounts up to $1500 \mu \mathrm{g}$ protein $/ \mathrm{ml}$ with other cations. All salts were supplied as chlorides apart from $\mathrm{ZnSO}_{4}$. Peptidase activity was assayed as described in the Methods. Activities of $100 \%$ correspond to 4.8 and $0.85 \mu \mathrm{mol}$ glycine released $/ \mathrm{min} / \mathrm{mg}$ protein for $\mathrm{Co}^{2+}$ (upper part of Table) and $\mathrm{Mn}^{2+}$ (lower part of Table) respectively. $\mathrm{P}$, potassium phosphate; $\mathrm{T}$, tris- $\mathrm{HCl}$.

Cation supplement ( $\mathrm{mm})$

\begin{tabular}{|c|c|c|c|c|c|c|c|c|c|c|c|c|}
\hline $\mathrm{Co}^{2+}$ & $\mathrm{Mg}^{2+}$ & $\mathrm{Zn}^{2+}$ & $\mathrm{Fe}^{2+}$ & $\mathrm{K}^{+}$ & $\mathrm{Ni}^{2+}$ & $\mathrm{Cu}^{2+}$ & $\mathrm{Cd}^{2+}$ & $\mathrm{Mn}^{2+}$ & EDTA & $\mathrm{Ca}^{2+}$ & & $(\%)$ \\
\hline 0.5 & - & - & - & - & - & - & - & - & - & 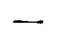 & $P$ & 100 \\
\hline 1.0 & - & 一 & 一 & - & - & - & - & - & - & - & $P$ & 100 \\
\hline 0.5 & $\mathrm{I} \cdot \mathrm{O}$ & - & - & - & - & - & - & - & - & - & $\mathbf{P}$ & 94 \\
\hline 0.5 & 0.5 & $\rightarrow$ & - & - & - & - & - & - & - & - & $\mathrm{P}$ & 100 \\
\hline- & $1 \cdot 0$ & - & - & - & - & - & - & - & - & - & $\mathrm{P}$ & 0 \\
\hline- & I.O & 一 & - & - & - & - & - & - & 0.25 & - & $\mathrm{P}$ & 0 \\
\hline- & $I \cdot 0$ & - & - & - & - & - & - & - & - & - & $T$ & 2 \\
\hline- & $I \cdot O$ & 一 & - & - & - & - & - & - & 0.25 & - & $\mathrm{T}$ & 2 \\
\hline$I \cdot O$ & - & $0.0 \mathrm{I}$ & - & - & - & - & - & - & - & - & $P$ & 100 \\
\hline$I \cdot O$ & - & $O \cdot I$ & - & - & - & 一 & - & - & - & - & $\mathbf{P}$ & 58 \\
\hline 10 & - & 一 & - & - & - & - & - & - & - & - & $\mathrm{T}$ & 19 \\
\hline $\mathrm{I} \cdot \mathrm{O}$ & - & 0.5 & - & - & - & - & - & - & - & - & $\mathrm{T}$ & 6 \\
\hline- & - & I. 0 & - & - & - & - & - & - & - & $\rightarrow$ & $\mathrm{P}$ & 0 \\
\hline$I \cdot O$ & - & - & $\mathrm{I} \cdot \mathrm{O}$ & - & - & - & - & - & - & - & $\mathrm{P}$ & 100 \\
\hline- & - & - & $\mathrm{I} \cdot \mathrm{O}$ & - & - & - & - & - & - & - & $\mathrm{P}$ & 0 \\
\hline$I \cdot O$ & - & - & - & $10 \cdot 0$ & - & - & - & - & - & - & $P$ & 100 \\
\hline $\mathrm{I} \cdot \mathrm{O}$ & - & - & - & $20 \cdot 0$ & - & - & 一 & - & - & - & $P$ & 86 \\
\hline- & - & - & - & $3 \cdot 0$ & - & - & - & - & - & - & $\mathbf{P}$ & 4 \\
\hline- & - & - & - & $3 \cdot 0$ & - & - & - & - & 0.25 & - & $\mathbf{P}$ & 4 \\
\hline- & - & - & - & $3 \cdot 0$ & - & - & - & - & - & - & $\mathrm{T}$ & 0 \\
\hline $\mathrm{I} \cdot \mathrm{O}$ & - & - & - & - & - & - & - & - & 0.25 & - & $\mathrm{P}$ & 108 \\
\hline $1 \cdot 0$ & - & - & - & - & I $\cdot O$ & - & - & - & - & - & $\mathbf{P}$ & 100 \\
\hline- & - & - & - & - & 3.0 & - & - & - & - & - & $\mathrm{P}$ & 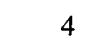 \\
\hline- & - & - & - & - & $3 \cdot 0$ & - & - & - & 0.25 & - & $\mathbf{P}$ & 3 \\
\hline- & - & - & - & - & 3.0 & - & - & - & - & - & $T$ & $J$ \\
\hline$I \cdot O$ & - & - & - & - & - & $I \cdot O$ & - & - & - & $\ldots$ & $\hat{P}$ & 41 \\
\hline$I \cdot O$ & - & - & - & - & - & 10.0 & - & - & - & - & $\mathrm{P}$ & 4 \\
\hline- & - & - & - & 一 & - & $1 \cdot 0$ & - & - & $\ldots$ & - & $P$ & 0 \\
\hline- & - & - & - & - & - & $20 \cdot 0$ & - & - & - & - & $P$ & 0 \\
\hline- & - & - & - & - & - & $20 \cdot 0$ & - & - & 0.25 & - & $P$ & o \\
\hline I.O & - & - & - & - & - & - & 0.1 & - & - & - & $\mathbf{P}$ & 7 \\
\hline $\mathrm{I} \cdot \mathrm{O}$ & - & - & - & - & - & - & 0.01 & - & - & - & $\mathbf{P}$ & 27 \\
\hline $\mathrm{I} \cdot \mathrm{O}$ & - & - & - & - & - & - & 0.005 & - & - & - & $\mathbf{P}$ & 37 \\
\hline$I \cdot O$ & 一 & - & - & - & - & - & $I \cdot O$ & - & - & - & $\mathrm{P}$ & 0 \\
\hline 0.5 & - & - & - & - & - & - & - & 0.5 & - & - & $\mathrm{P}$ & 103 \\
\hline 0.5 & - & 一 & - & - & - & - & - & 1.0 & - & - & $\mathbf{P}$ & 89 \\
\hline$I \cdot O$ & - & - & - & - & - & - & - & $I \cdot 0$ & - & - & $P$ & II 4 \\
\hline$I \cdot O$ & - & - & - & - & - & - & - & 3.0 & - & - & $\mathbf{P}$ & 53 \\
\hline$I \cdot O$ & $\cdots$ & - & - & - & - & 一 & - & $10 \cdot 0$ & - & - & $\mathbf{P}$ & $3 \mathrm{I}$ \\
\hline$I \cdot C$ & - & - & - & - & - & - & - & - & - & $I \cdot O$ & $\mathbf{P}$ & IOO \\
\hline- & - & - & - & - & - & 一 & - & - & - & $\mathrm{I} \cdot \mathrm{O}$ & $\mathbf{P}$ & \\
\hline$I \cdot O$ & - & - & - & - & - & 一 & - & - & - & $\mathrm{I} \cdot \mathrm{O}$ & $\mathrm{T}$ & 22 \\
\hline - & - & - & - & - & - & - & - & $I \cdot O$ & - & - & $\mathbf{P}$ & 100 \\
\hline- & - & - & - & - & - & - & - & $I \cdot 0$ & 0.25 & - & $\mathrm{P}$ & 122 \\
\hline 0.5 & - & - & - & - & - & - & - & 0.5 & - & - & $\mathbf{P}$ & 53 \\
\hline- & - & - & 一 & 10.0 & - & - & - & $\mathrm{I} \cdot \mathrm{O}$ & - & - & $\mathbf{P}$ & 89 \\
\hline- & - & 0.01 & - & - & - & - & - & $\mathrm{I} \cdot \mathrm{O}$ & - & - & $P$ & 26 \\
\hline - & - & $0 \cdot I$ & - & - & - & - & - & $I \cdot O$ & - & - & $P$ & \\
\hline- & 一 & 0.5 & - & - & - & - & $\ldots$ & $\mathrm{I} \cdot \mathrm{O}$ & $\ldots$ & - & $T$ & \\
\hline
\end{tabular}


Table I (cont.)

Cation supplement (mM)

\begin{tabular}{|c|c|c|c|c|c|c|c|c|c|c|c|c|}
\hline $\mathrm{Co}^{2+}$ & $\mathrm{Mg}^{2+}$ & $\mathrm{Zn}^{2+}$ & $\mathrm{Fe}^{2+}$ & $\mathrm{K}^{+}$ & $\mathrm{Ni}^{2++}$ & $\mathrm{Cu}^{2+}$ & $\mathrm{Cd}^{2+}$ & $\mathrm{Mn}^{2+}$ & EDTA & $\mathrm{Ca}^{2+}$ & & $(\%)$ \\
\hline- & - & - & - & - & - & - & $\ldots$ & I.O & - & - & $T$ & 98 \\
\hline - & - & -- & - & - & - & $\ldots$ & - & 1.0 & 0.25 & - & $\mathrm{T}$ & 130 \\
\hline- & - & - & - & - & - & 1.0 & - & 1.0 & - & - & $P$ & 14 \\
\hline- & - & - & - & - & $\cdots$ & 10.0 & - & 1.0 & - & - & $\mathrm{P}$ & 0 \\
\hline- & - & - & - & - & - & - & 0.01 & 1.0 & - & - & $P$ & 12 \\
\hline- & - & - & - & - & - & - & 0.1 & $I 0$ & - & - & $P$ & 5 \\
\hline- & - & - & - & - & - & - & - & $1 \cdot 0$ & - & $\mathrm{I} \cdot \mathrm{O}$ & $P$ & 115 \\
\hline- & - & - & - & - & - & - & - & $I \cdot O$ & - & I.O & $\mathrm{T}$ & I 25 \\
\hline
\end{tabular}

Growth of bacteria and preparation of crude extracts

For most studies here, Escherichia coli B (MRE strain I60) was grown in a chemostat under conditions of carbon limitation at a dilution rate of $0.18 \mathrm{~h}^{-1}$, and harvested at $E_{540}=10.3$ (dry wt $4.4 \mathrm{mg} / \mathrm{ml}$ ). In one case batch culture was used. Both these procedures are described elsewhere (Payne, 1972). The strains employed and batch growth of E. coli W and KI 2 have been described previously (Payne, I97I $a$ ). Bacteria were disrupted, and crude extracts were prepared as described elsewhere (Payne, 1972). Protein concentrations were kindly determined by Dr H. E. Wade by an automated Folin-Ciocalteu procedure (Wade \& Phillips, 1971).

\section{Peptidase assay}

The procedure of Binkley, Leibach \& King (1968), employing trinitrobenzene sulphonate (TNBS) was used. In this method, the presence of $\mathrm{Cu}^{2+}$ in the reagent solution effectively prevents reaction of the TNBS with the peptide $\alpha$-amino group while allowing its reaction with the $\alpha$-amino groups of the amino acids liberated by peptidase hydrolysis. It therefore has the advantage over most assays employing ninhydrin that the peptide 'blank' values are low. In exploring the optimum conditions for peptidase action, the individual components of the incubation mixture were varied widely as shown in the Results section. However, a standard incubation mixture of I ml comprised: peptide, $7.5 \mathrm{mM}$; $\mathrm{Co}^{2+}$ or $\mathrm{Mn}^{2+}$, I mM; EDTA, $0.25 \mathrm{mM}$; buffer, $20 \mathrm{mM}$; and crude extract containing, when diglycine was substrate, approximately $15 \mu \mathrm{g}$ protein $/ \mathrm{ml}$ with $\mathrm{Co}^{2+}$ or $75 \mu \mathrm{g}$ protein $/ \mathrm{ml}$ with $\mathrm{Mn}^{2+}$, and approximately five times these amounts of protein when using divaline or prolylglycine. The reaction was started by the addition of protein to the test mixture previously equilibrated to $37^{\circ} \mathrm{C}$ and incubation was continued at this temperature. At zero time, and at three or four intervals thereafter up to $80 \mathrm{~min}$, samples $(0 . \mathrm{Iml})$ were removed and added to the $\mathrm{TNBS}^{-\mathrm{Cu}^{2+}}$ reagent solution $(4.5 \mathrm{ml})$. These were incubated at $37^{\circ} \mathrm{C}$ for exactly $20 \mathrm{~min}$ when hydrochloric acid (II.6 M, O.I ml) was immediately added, the solutions were mixed and the $E_{420}$ were recorded. Calibration curves for the amino acid constituents of the peptides were prepared by similar procedures. Proline does not react with TNBS under the above assay conditions, and when prolylglycine was used as substrate the total concentration of amino acid released was therefore taken as twice the value obtained for glycine.

\section{RESULTS}

The peptidase activity of crude extracts

The peptidase activities (expressed as $\mu \mathrm{mol}$ amino acid released $/ \mathrm{min} / \mathrm{mg}$ of protein) of crude extracts measured in incubation mixtures containing peptide $(7.5 \mathrm{~mm})$ and either 
potassium phosphate $\mathrm{pH} 7.5(20 \mathrm{mM})$ or tris- $\mathrm{HCl} \mathrm{pH} 7.9(20 \mathrm{mM})$ respectively were 0.012 and 0.018 with diglycine, 0.018 and 0.003 with divaline and 0.004 and 0.003 with prolylglycine. When dialysed extracts were used, the activities were unchanged.

\section{The effect of cations on the peptidase activity of crude extracts}

Bacterial peptidases frequently require metal ions for activity (Sarid, Berger \& Katchalski, I959, I962; Simmonds \& Toye, I967; Yaron \& Mlynar, I968; Simmonds, I970; Sussman \& Gilvarg, 1970; Vogt, 1970). Using diglycine as substrate, a potentiating effect was also observed here when crude extracts were supplemented with certain cations (Table I). Of the divalent cations tested, $\mathrm{Co}^{2+}$ and $\mathrm{Mn}^{2+}$ specifically activated the cleavage of diglycine approximately 500 and 60 times respectively. With the present assay procedure cation stimulation was immediate, and there appears to be no advantage in prolonged activation procedures as are required, for example, with leucine aminopeptidase (Smith, I95I). The cations $\mathrm{Mg}^{2+}, \mathrm{Zn}^{2+}, \mathrm{Fe}^{2+}, \mathrm{Ni}^{2+}, \mathrm{Cu}^{2+}, \mathrm{Cd}^{2+}$, and $\mathrm{K}^{+}$were all without significant potentiating action, while $\mathrm{Cd}^{2+}$ and $\mathrm{Zn}^{2+}$, and to a lesser extent $\mathrm{Cu}^{2+}$, all antagonized the activation by $\mathrm{Co}^{2+}$ and $\mathrm{Mn}^{2+}$. These observations on the inhibitory properties of $\mathrm{Zn}^{2+}$ and $\mathrm{Cd}^{2+}$ extend the findings of others (Sarid et al. 1962; Simmonds, 1970; Vogt, 1970). The studies were extended to divaline and to prolylglycine and the effects of $\mathrm{Co}^{2+}$ and $\mathrm{Mn}^{2+}$ concentration on the cleavage of all three peptides is shown in Fig. I and 2. For $\mathrm{Co}^{2+}$ activation (Fig. I) in phosphate buffer, optimum cation concentration was within a narrow range around I $\mathrm{mm}$ for all three substrates; in tris buffer the optimum $\mathrm{Co}^{2+}$ concentration for the cleavage of diglycine was somewhat higher, about $5 \mathrm{mM}$. In all cases, higher concentrations of $\mathrm{Co}^{2+}$ led to marked inhibition of activity. With $\mathrm{Mn}^{2+}$ as activator (Fig. 2), the variation of activity (towards different substrates) as a function of concentration was greater than was observed with $\mathrm{Co}^{2+}$. For example, in phosphate buffer, diglycine and divaline both showed optimal cleavage around I $\mathrm{mM}-\mathrm{Mn}^{2+}$, whereas maximum cleavage of prolylglycine required about $7 \mathrm{mM}-\mathrm{Mn}^{2+}$. In contrast to $\mathrm{Co}^{2+}$ activated cleavage, the $\mathrm{Mn}^{2+}$ activated] hydrolysis of diglycine showed the same rate and concentration dependence in tris as in phosphate buffer. Although a high ionic strength is required by certain carboxypeptidases (Smith, I95I), the results with added $\mathrm{K}^{+}$ions indicated that with neither $\mathrm{Co}^{2+}$ nor $\mathrm{Mn}^{2+}$ did high ionic strength stimulate hydrolytic activity, in fact the opposite was observed (Table I); this result therefore argues against the routine inclusion of $\mathrm{K}^{+}$or $\mathrm{Na}^{+}$in assay mixtures.

\section{Effect of EDTA on peptidase activity}

When tested in phosphate buffer $\mathrm{pH} \mathrm{7.5}$, the addition of EDTA (0.05 to $0.20 \mathrm{~mm})$ slightly stimulated the $\mathrm{Co}^{2+}$ (I $\mathrm{mM}$ ) activated hydrolysis of diglycine and stimulated the $\mathrm{Mn}^{2+}$ (I mM) activated cleavage more (Table r). On further increasing the EDTA concentration to $0.5 \mathrm{mM}$ the rate of both $\mathrm{Mn}^{2+}$ ( $\mathrm{I} \mathrm{mM}$ ) and $\mathrm{Co}^{2+}$ activated cleavage decreased.

\section{Effect of cysteine on peptidase activity}

Cysteine activates certain proteases (Smith, I95I), and peptidases (Stone, I953) but inhibits others, e.g. leucine aminopeptidase (Smith, 195I). Using the extracts here (Table 2), cysteine alone ( $5 \mathrm{~mm}$ ) did not stimulate hydrolysis of diglycine, or divaline or prolylglycine; on the contrary it slightly inhibited the $\mathrm{Mn}^{2+}$ activated cleavage of these dipeptides and markedly inhibited the $\mathrm{Co}^{2+}$ activated hydrolysis. The inhibition with $\mathrm{Co}^{2+}$ presumably arises from reduction of the free cation concentration as a result of cysteine- $\mathrm{Co}^{2+}-$ complex formation (Michaelis \& Schubert, 1930). 


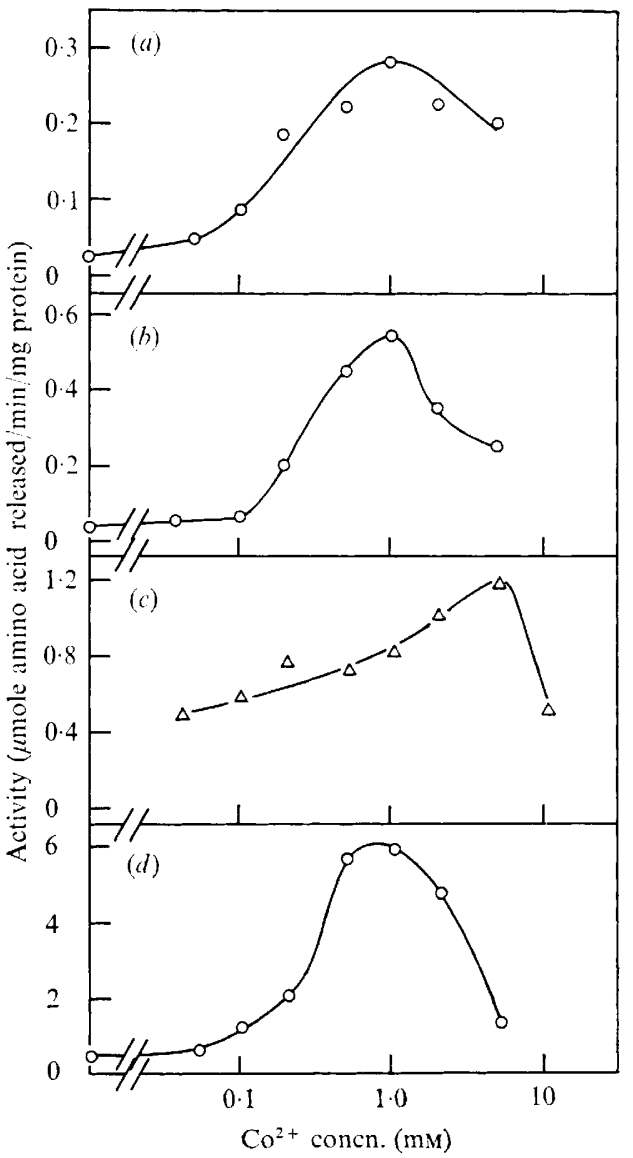

Fig. I

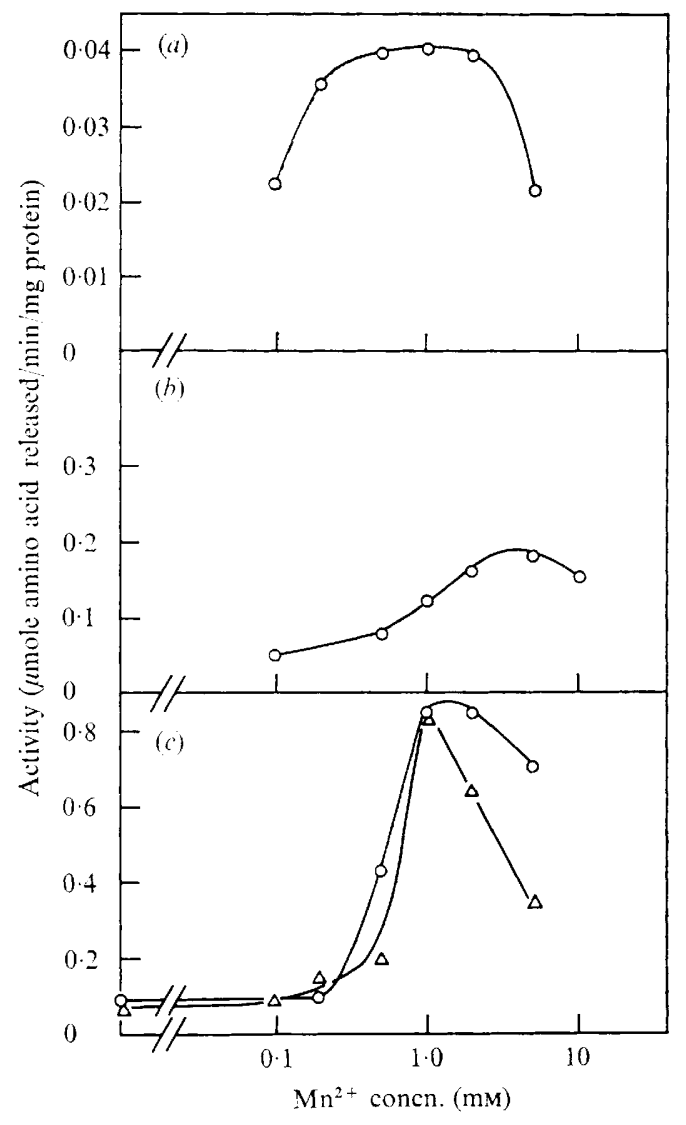

Fig. 2

Fig. 1. The effect of $\mathrm{Co}^{2+}$ concentration on the cleavage of divaline $(a)$, prolylglycine $(b)$, and diglycine $(c, d)$ by crude extracts. Incubation mixtures $(\mathrm{I} \mathrm{ml})$ contained peptide $(7.5 \mathrm{mM})$ and either potassium phosphate $\mathrm{pH} 7.5(20 \mathrm{mM})$ or tris- $\mathrm{HCl} \mathrm{pH} \mathrm{7.9}(20 \mathrm{mM})$, and indicated amounts of $\mathrm{Co}^{2+}$; crude extract was added to give, with divaline, prolylglycine and diglycine, approximately 300, I 50 and $20 \mu \mathrm{g}$ protein $/ \mathrm{ml}$ respectively. Peptidase assays were performed as described in Methods. $\bigcirc$, Potassium phosphate; $\triangle$, tris- $\mathrm{HCl}$.

Fig. 2. The effect of $\mathrm{Mn}^{2+}$ concentration on the cleavage of divaline (a), prolylglycine $(b)$, and diglycine $(c)$ by crude extracts. Incubation mixtures contained peptide $(7.5 \mathrm{~mm})$ and either potassium phosphate $\mathrm{pH} 7.5(20 \mathrm{mM})$ or tris- $\mathrm{HCl} \mathrm{pH} \mathrm{7.9} \mathrm{(20} \mathrm{mM),} \mathrm{and} \mathrm{indicated} \mathrm{amounts} \mathrm{of} \mathrm{Mn}^{2+}$; crude extract was added to give with divaline, prolylglycine and diglycine approximately 1500,750 , and $75 \mu \mathrm{g}$ protein $/ \mathrm{ml}$ respectively. Peptidase assays were performed as described in Methods. $\bigcirc$, Potassium phosphate; $\triangle$, tris- $\mathrm{HCl}$.

\section{Effect of $\mathrm{pH}$ and buffer on $\mathrm{Co}^{2+}$ activated peptidase}

The effects of $\mathrm{pH}$ on the $\mathrm{Co}^{2+}$ activated cleavage of diglycine, divaline and prolyglycine are shown in Fig. 3. The diglycine-splitting enzyme was active over a wide $\mathrm{pH}$ range, with a broad maximum around $\mathrm{pH} 7 \cdot 8$ (Fig. $3 c$ ). However, although the buffers used provided overlapping $\mathrm{pH}$ profiles, for a given $\mathrm{pH}$ the absolute activities varied greatly depending on the nature of the buffer used. Certain aspects of the influence of buffers on peptidase activity were studied further and the results are shown in Table 3. For example, with diglycine as substrate, the activity in phosphate was about five times greater than that measured 
Table 2. The effect of cysteine on the cleavage of diglycine, prolylglycine, and divaline

The incubation mixtures (I ml) contained peptide $(7.5 \mathrm{mM})$, potassium phosphate $\mathrm{pH} 7.5$ $(20 \mathrm{mM})$, and supplements as indicated. Crude extracts were added to give approximately $15 \mu \mathrm{g}$ protein with $\mathrm{Co}^{2+}$ and diglycine, approximately $50 \mu \mathrm{g}$ with $\mathrm{Co}^{2+}$ and other peptides and with $\mathrm{Mn}^{2+}$ and diglycine, and approximately $300 \mu \mathrm{g}$ protein with other mixtures. Peptidase activity was assayed as described in Methods, and is expressed as $\mu \mathrm{mol}$ amino acid released $/ \mathrm{min} / \mathrm{mg}$ protein.

$\begin{array}{lcccc}\begin{array}{c}\text { Peptide } \\ \text { Diglycine }\end{array} & \begin{array}{c}\text { Supplements to crude extracts } \\ \text { Concn (mM) }\end{array} \\ \text { Diglycine } & \mathrm{Co}^{2+} & \mathrm{Mn}^{2+} & \text { Cysteine } & \text { Activity } \\ \text { Diglycine } & \text { I } & - & - & 0.01 \\ \text { Diglycine } & \text { I } & - & - & 5.25 \\ \text { Diglycine } & - & \text { I } & - & 0.72 \\ \text { Diglycine } & - & \text { I } & 5 & 0.00 \\ \text { Prolylglycine } & - & - & - & 0.02 \\ \text { Prolylglycine } & \text { I } & - & - & 0.01 \\ \text { Prolylglycine } & \text { I } & - & 5 & 0.19 \\ \text { Prolylglycine } & - & \text { I } & - & 0.08 \\ \text { Prolylglycine } & - & \text { I } & 5 & 0.08 \\ \text { Prolylglycine } & - & - & 5 & 0.01 \\ \text { Divaline } & - & - & - & 0.02 \\ \text { Divaline } & \text { I } & - & - & 0.38 \\ \text { Divaline } & \text { I } & - & 5 & 0.06 \\ \text { Divaline } & - & \text { I } & - & 0.04 \\ \text { Divaline } & - & \text { I } & 5 & 0.02 \\ \text { Divaline } & - & - & 5 & 0.02\end{array}$

in tris- $\mathrm{HCl}$, and this difference was preserved over a range of $\mathrm{pH}$ values (Fig. 3) and at various concentrations of $\mathrm{Co}^{2+}$ (Fig. I). The cleavage of divaline and prolylglycine was also maximal in phosphate buffer although the enhancement was not so marked as with diglycine. The reason for the stimulatory effect of phosphate is not known but did not arise from its ability to reverse possible inhibition by contaminating $\mathrm{Ca}^{2+}$ ions, as has been reported for other peptidases (Smith, I95I; Kenny, WongLeung \& Ingram, I968), for the addition of $\mathrm{Ca}^{2+}$ ions was without effect on activity (Table I). With tris, decreasing its concentration did not lead to greater activity, neither did increasing its concentration further reduce the rate of diglycine hydrolysis, suggesting that tris per se was not inhibitory (Table 3). In fact, increasing the concentration of tris from 20 to $80 \mathrm{~mm}$ increased the hydrolysis of diglycine, whereas a similar increase in the concentration of phosphate buffer decreased cleavage (Table 3). On the other hand, the addition of phosphate ions to the tris buffer markedly stimulated the diglycine splitting activity. Veronal buffer inhibited the $\mathrm{Co}^{2+}$ activated cleavage at all $\mathrm{pH}$ values tested (Fig. 3), and in this case activity could not be restored by addition of phosphate ions to the incubation mixture.

\section{Effect of $\mathrm{pH}$ and buffer on $\mathrm{Mn}^{2+}$ activated peptidase}

The $\mathrm{Mn}^{2+}$ activated cleavage of diglycine, divaline and prolylglycine (Fig. 4) occurs over a wide $\mathrm{pH}$ range with an optimum in each case at about $\mathrm{pH} 8$. In contrast to the variable activities found with $\mathrm{Co}^{2+}$, when $\mathrm{Mn}^{2+}$ was used essentially equal activities were observed for a given $\mathrm{pH}$ irrespective of the buffer used. It is especially noteworthy that the activity was in no way inhibited by veronal. Increasing the concentration of tris in the incubation mixture 


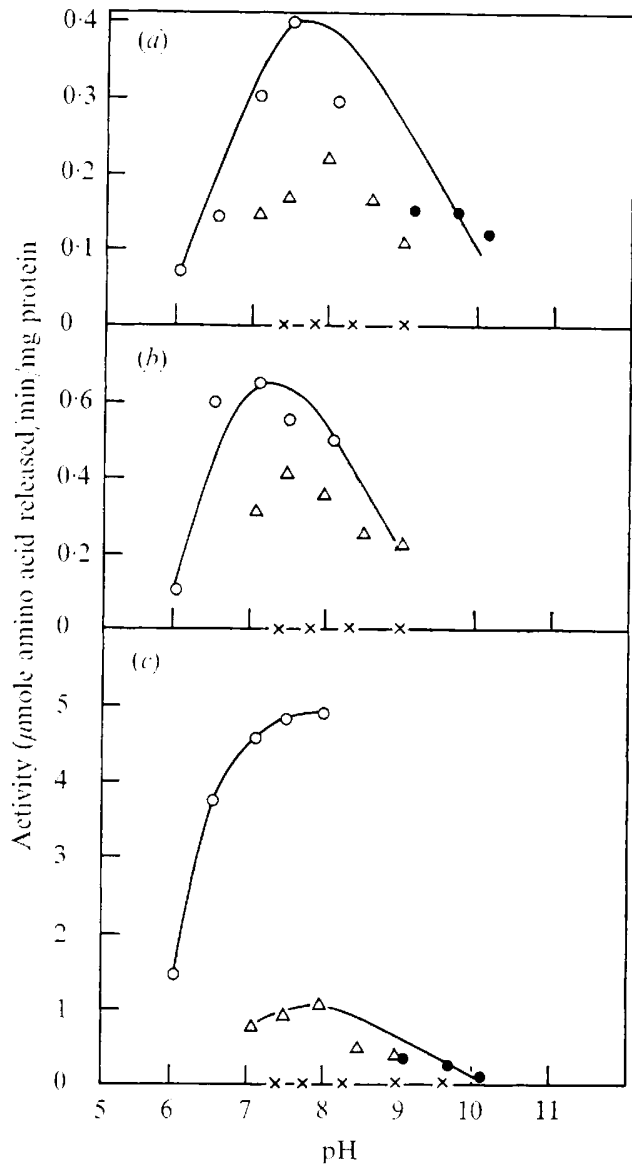

Fig. 3

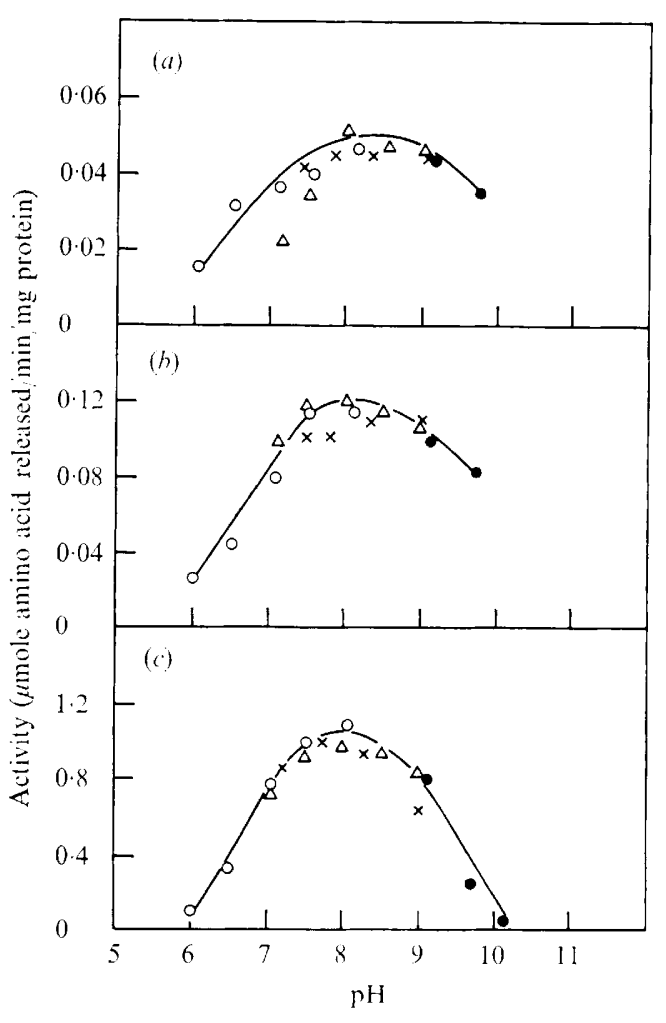

Fig. 4

Fig. 3. The effect of $\mathrm{pH}$ on the $\mathrm{Co}^{2+}$ activated hydrolysis of divaline $(a)$, prolylglycine $(b)$ and diglycine $(c)$. Incubation mixtures (I ml) contained peptide $(7 \cdot 5 \mathrm{~mm})$, EDTA $(0 \cdot 25 \mathrm{mM}), \mathrm{Co}^{2+}(\mathrm{I} \mathrm{mM})$, buffer $(20 \mathrm{~mm})$ and crude extract (with divaline and prolylglycine approximately $100 \mu \mathrm{g}$ protein and with diglycine approximately $20 \mu \mathrm{g}$ protein). Peptidase assays were performed as described in Methods. The buffers used were: $O$, potassium phosphate; $\triangle$, tris- $\mathrm{HCl} ; \boldsymbol{\theta}$, carbonate; $\times$, veronal.

Fig. 4. The effect of $\mathrm{pH}$ on the $\mathrm{Mn}^{2+}$ activated cleavage of divaline $(a)$, prolylglycine $(b)$, and diglycine $(c)$. Incubation mixtures (I ml) contained peptide ( $7 \cdot 5 \mathrm{~mm})$, EDTA (o.25 mM), $\mathrm{Mn}^{2+}(\mathrm{I} \mathrm{mM})$, buffer $(20 \mathrm{~mm})$ and crude extract (approximately $200 \mu \mathrm{g}$ protein). Peptidase assays were performed as described in Methods. The buffers used were: $O$, potassium phosphate; $\triangle$, tris- $\mathrm{HCl}$; carbonate; $x$, veronal.

slightly increased the activity at all $\mathrm{pH}$ values tested, whereas a decrease in hydrolysis resulted from comparable increases in the concentration of phosphate buffer (Table 3).

\section{The effect of substrate concentration on $\mathrm{Co}^{2+}$ peptidase activity}

The variation in the rates of cleavage of diglycine, prolylglycine and divaline as a function of dipeptide concentration is shown in Fig. 5. In each case, over an appropriate concentration range the relationship between the extent of hydrolysis and the substrate concentration was linear in short-duration experiments. The enzymes appear to be saturated at substrate concentrations of approximately $2 \cdot 5,3$, and $6 \mathrm{~mm}$ for divaline, prolylglycine and diglycine respectively. In most standard incubation mixtures, the dipeptides were used at concentra- 
Table 3. The influence of buffer concentration and phosphate ions on the cleavage of diglycine by crude extracts

Standard incubations and peptidase assays were performed as described in Methods. Peptidase activities are expressed as $\mu$ mole glycine released $/ \mathrm{min} / \mathrm{mg}$ of protein.

\begin{tabular}{|c|c|c|c|c|c|c|}
\hline & Buffer & & Supp & lement & & \\
\hline Type & $\mathrm{pH}$ & Concn (mM) & Type & Concn (mM) & Cation & Activity \\
\hline Tris & $7 \cdot 47$ & Io & 一 & - & $\mathrm{Co}^{2+}$ & 0.91 \\
\hline Tris & $7 \cdot 47$ & 20 & - & - & $\mathrm{Co}^{2+}$ & 0.91 \\
\hline Tris & $7 \cdot 47$ & 75 & - & 一 & $\mathrm{Co}^{2+}$ & $1 \cdot 62$ \\
\hline Tris & $7 \cdot 90$ & 10 & 一 & - & $\mathrm{Co}^{2+}$ & 0.92 \\
\hline Tris & $7 \cdot 90$ & 20 & - & 一 & $\mathrm{Co}^{2+}$ & 0.92 \\
\hline Tris & $7 \cdot 90$ & 75 & - & - & $\mathrm{Co}^{2+}$ & $\mathrm{I} \cdot 45$ \\
\hline Phosphate & $7 \cdot 50$ & 4 & 一 & - & $\mathrm{Co}^{2+}$ & $4 \cdot 60$ \\
\hline Phosphate & $7 \cdot 50$ & 10 & - & - & $\mathrm{Co}^{2+}$ & $4 \cdot 84$ \\
\hline Phosphate & $7 \cdot 50$ & 20 & - & - & $\mathrm{Co}^{2+}$ & $4 \cdot 84$ \\
\hline Phosphate & $7 \cdot 50$ & 40 & 一 & 一 & $\mathrm{Co}^{2+}$ & 4.00 \\
\hline Phosphate & $7 \cdot 50$ & 75 & - & - & $\mathrm{Co}^{2+}$ & $2 \cdot 32$ \\
\hline Phosphate & $8 \cdot 10$ & 20 & 一 & - & $\mathrm{Co}^{2+}$ & $4 \cdot 90$ \\
\hline Phosphate & $8 \cdot 10$ & 75 & - & 一 & $\mathrm{Co}^{2+}$ & $2 \cdot 74$ \\
\hline Tris & $7 \cdot 47$ & 20 & $\mathrm{~K}_{2} \mathrm{HPO}_{4}$ & 20 & $\mathrm{Co}^{2+}$ & $4^{\cdot 15}$ \\
\hline Tris & $7 \cdot 90$ & 20 & $\mathrm{KH}_{2} \mathrm{PO}_{4}$ & 2 & $\mathrm{Co}^{2+}$ & $1 \cdot 25$ \\
\hline Tris & $7 \cdot 90$ & 20 & $\mathrm{KH}_{2} \mathrm{PO}_{4}$ & 20 & $\mathrm{Co}^{2+}$ & $2 \cdot 34$ \\
\hline Tris & $7 \cdot 90$ & 20 & $\mathrm{~K}_{2} \mathrm{HPO}_{4}$ & 2 & $\mathrm{Co}^{2+}$ & $1 \cdot 00$ \\
\hline Tris & $7 \cdot 90$ & 20 & $\mathrm{~K}_{2} \mathrm{HPO}_{4}$ & 20 & $\mathrm{Co}^{2+}$ & $2 \cdot 6 I$ \\
\hline Tris & $8 \cdot 51$ & 20 & - & - & $\mathrm{Co}^{2+}$ & 0.75 \\
\hline Tris & $8 \cdot 5 \mathrm{I}$ & 20 & $\mathrm{~K}_{2} \mathrm{HPO}_{4}$ & 20 & $\mathrm{Co}^{2+}$ & $2 \cdot 68$ \\
\hline Veronal & $7 \cdot 80$ & 10 & - & 一 & $\mathrm{Co}^{2+}$ & 0.00 \\
\hline Veronal & $7 \cdot 80$ & 10 & $\mathrm{KH}_{2} \mathrm{PO}_{4}$ & 2 & $\mathrm{Co}^{2+}$ & 0.00 \\
\hline Veronal & $7 \cdot 80$ & IO & $\mathrm{KH}_{2} \mathrm{PO}_{4}$ & 20 & $\mathrm{Co}^{2+}$ & 0.07 \\
\hline Veronal & $7 \cdot 80$ & 10 & $\mathrm{~K}_{2} \mathrm{HPO}_{4}$ & 2 & $\mathrm{Co}^{2+}$ & 0.00 \\
\hline Veronal & $7 \cdot 80$ & 10 & $\mathrm{~K}_{2} \mathrm{HPO}_{4}$ & 20 & $\mathrm{Co}^{2+}$ & 0.09 \\
\hline Tris & $7 \cdot 47$ & $2 \mathrm{C}$ & - & - & $\mathrm{Mn}^{2+}$ & 0.58 \\
\hline Tris & $7 \cdot 47$ & 80 & 一 & - & $\mathrm{Mn}^{2+}$ & 0.93 \\
\hline Tris & $7 \cdot 90$ & 20 & - & - & $\mathrm{Mn}^{2+}$ & 0.84 \\
\hline Tris & $7 \cdot 90$ & 80 & - & - & $\mathrm{Mn}^{2+}$ & $I \cdot 14$ \\
\hline Phosphate & $7 \cdot 50$ & 20 & - & - & $\mathrm{Mn}^{2+}$ & 0.85 \\
\hline Phosphate & $7 \cdot 50$ & 80 & - & - & $\mathrm{Mn}^{2+}$ & 0.27 \\
\hline Phosphate & $8 \cdot 10$ & 20 & - & 一 & $\mathrm{Mn}^{2+}$ & $0 \cdot 8 I$ \\
\hline Phosphate & $8 \cdot 10$ & 80 & - & - & $\mathrm{Mn}^{2+}$ & $0 \cdot 16$ \\
\hline
\end{tabular}

tions of $7.5 \mathrm{~mm}$. Lineweaver-Burk plots, for the hydrolysis of the three dipeptides, are also shown in Fig. 5. The apparent $K_{m}$ values for divaline, prolylglycine and diglycine are $6.5 \times 10^{-3} \mathrm{M}, 2.5 \times 10^{-3} \mathrm{M}$, and $2.0 \times 10^{-3} \mathrm{M}$ respectively.

\section{Effect of substrate concentration on $\mathrm{Mn}^{2+}$ peptidase activity}

This was studied using diglycine as substrate (Fig. 6). In short-duration experiments, a linear relationship again exists between the amount of glycine released and the substrate concentration within an appropriate concentration range, with the enzyme apparently saturated at substrate concentrations in excess of $6 \mathrm{mM}$. A Lineweaver-Burk plot of the data indicates an apparent $K_{m}$ of $9 \cdot 1 \times 10^{-3} \mathrm{M}$.

\section{Effect of protein concentration on $\mathrm{Co}^{2+}$ activated cleavage of diglycine}

For short incubation periods $(20 \mathrm{~min})$, the relationship between the amount of glycine liberated and the amount of protein present in the reaction mixture was linear up to about O. I $\mathrm{mg}$ of protein $/ \mathrm{ml}$. 


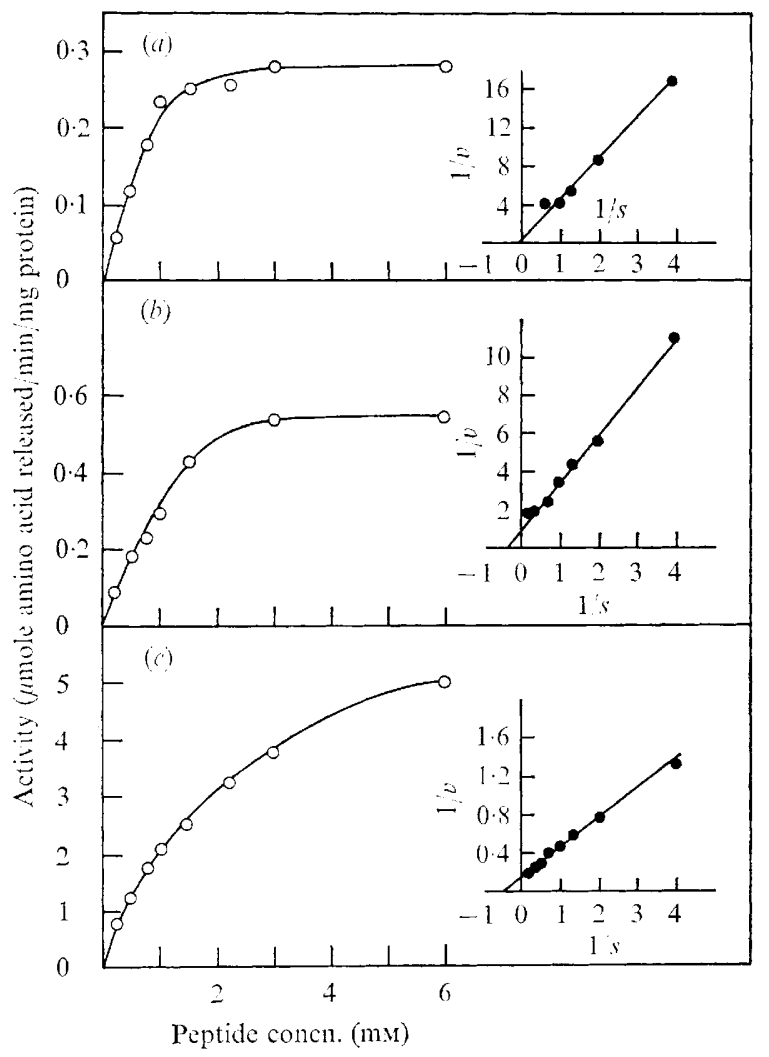

Fig. 5. The effect of substrate concentration on the rate of $\mathrm{Co}^{2+}$ activated hydrolysis of divaline $(a)$, prolylglycine $(b)$, and diglycine $(c)$. The incubation mixtures contained potassium phosphate $\mathrm{pH} 7 \cdot 5$ $(20 \mathrm{mM})$, EDTA $(0.25 \mathrm{mM}), \mathrm{Co}^{2+}$ (I $\left.\mathrm{mM}\right)$, and the indicated amounts of dipeptide substrates. Crude extracts were added to give approximately $\mathrm{I} 5 \mu \mathrm{g}$ protein with diglycine as substrate and approximately $75 \mu \mathrm{g}$ protein with divaline and prolylglycine. Peptidase assays were performed as described in Methods. Inserts are Lineweaver-Burk plots of the data; $1 / v, \mu \mathrm{mol}$ amino acid released per min; $\mathrm{I} / \mathrm{s}$, peptide concn $\left(\mathrm{mm}^{-1}\right)$.

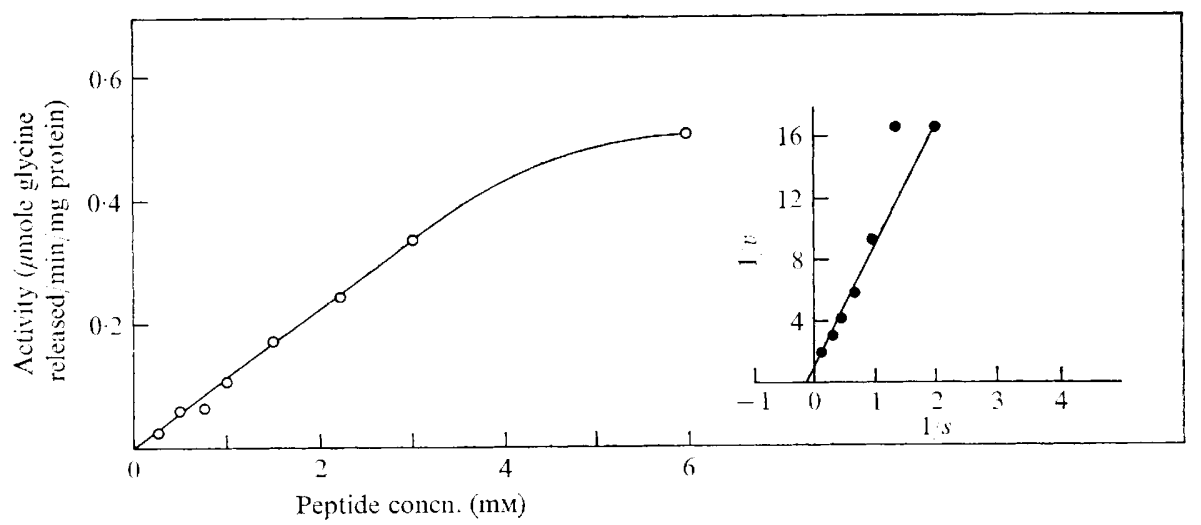

Fig. 6. The effect of substrate concentration on the rate of $\mathrm{Mn}^{2+}$ activated hydrolysis of diglycine. The incubation mixtures $(1 \mathrm{ml})$ contained potassium phosphate buffer $\mathrm{pH} 7.5$ (20 mM), EDTA $(0.25 \mathrm{mM}), \mathrm{Mn}^{2+}$ (I mM), and crude extract ( $75 \mu \mathrm{g}$ protein), together with the indicated amounts of diglycine. Peptidase assays were performed as described in Methods. Inset is Lineweaver-Burk plot of the data; $\mathrm{I} / v, \mu \mathrm{mol}$ amino acid released per min; $\mathrm{I} / s$, peptide concn $\left(\mathrm{mM}^{-1}\right)$. 
Table 4. The substrate specificities of $\mathrm{Co}^{2+}$ and $\mathrm{Mn}^{2+}$ activated peptidases

The incubation mixtures ( $1 \mathrm{ml})$ contained peptide $(5 \mathrm{~mm})$, EDTA $(0.25 \mathrm{~mm})$, potassium phosphate pH $7.5(20 \mathrm{mM})$, crude extract was added to give approximately $750 \mu \mathrm{g}$ protein $/ \mathrm{ml}$ with $\mathrm{Mn}^{2+}$ (I $\mathrm{mM}$ ) and with the unsupplemented mixture, and $\mathrm{I} 50 \mu \mathrm{g}$ protein $/ \mathrm{ml}$ with $\mathrm{Co}^{2+}$ (I mM). Peptidase activity was assayed as described in Methods. Peptidase activities are expressed as $\mu \mathrm{mol}$ amino acid released $/ \mathrm{min} / \mathrm{mg}$ of protein, and are calculated using the appropriate extinction coefficients for each amino acid.

\begin{tabular}{lccc}
\multicolumn{4}{c}{ Activity of crude extract supplemented } \\
\cline { 2 - 4 } \multicolumn{1}{c}{ Peptide } & No ion & $\mathrm{Mn}^{2+}$ & $\mathrm{Co}^{2+}$ \\
Pro-Gly & 0.004 & 0.082 & 0.540 \\
Gly-Pro & 0.042 & 0.028 & 0.127 \\
Pro-Val & 0.009 & 0.023 & 0.042 \\
Pro-Tyr & 0.000 & 0.025 & 0.042 \\
Pro-Phe & 0.009 & 0.036 & 0.085 \\
Gly-Lys & 0.055 & 0.049 & 0.860 \\
Lys-Gly & 0.036 & 0.079 & 0.615 \\
Lys-Lys & 0.066 & $0.05 \mathrm{I}$ & 0.382 \\
Leu-Phe & 0.032 & 0.042 & 0.466 \\
Leu-Tyr & 0.032 & 0.045 & 0.312 \\
Val-Val & 0.018 & $0.04 \mathrm{I}$ & $0.38 \mathrm{I}$ \\
Val-Gly & 0.007 & 0.012 & 0.498 \\
Gly-Val & 0.002 & 0.045 & 0.360 \\
Gly-Gly & 0.012 & $\mathrm{I} .000$ & 5.250 \\
Gly-Leu & 0.004 & $0.02 \mathrm{I}$ & $0.19 \mathrm{I}$ \\
Gly-Phe & 0.032 & 0.085 & 0.222 \\
Gly-His & 0.042 & 0.072 & 0.106 \\
Gly-Tyr & 0.070 & 0.094 & 0.816 \\
$\alpha-G l u-G l y$ & 0.000 & 0.015 & 0.202 \\
$\gamma$-Glu-Gly & 0.000 & 0.003 & $0.01 \mathrm{I}$ \\
$\alpha$-Asp-Ala & 0.002 & 0.038 & 0.032 \\
$\beta$-Asp-Ala & 0.006 & 0.009 & 0.005 \\
& & &
\end{tabular}

The substrate specificities of the $\mathrm{Co}^{2+}$ and $\mathrm{Mn}^{2+}$ activated peptidases

One reason for selecting diglycine, divaline and prolylglycine for study was the assumption that their cleavage by crude extracts was likely to be effected by separate peptidases of limited specificities. However, the results presented so far suggest that the $\mathrm{Co}^{2+}$ (and perhaps also the $\mathrm{Mn}^{2+}$ ) activities may well reside in only one enzyme, unless several peptidases of remarkably similar properties are present. Isolating and purifying the individual peptidases was outside the present objectives of assessing the main peptidase activities of the bacteria, but to study this aspect further we measured the effects of $\mathrm{Co}^{2+}$ and $\mathrm{Mn}^{2+}$ on the cleavage of a wider selection of dipeptides. Several general conclusions emerge from the data shown in Table 4. First, the crude extracts displayed uniformly low activity towards a broad spectrum of dipeptides; secondly, $\mathrm{Co}^{2+}$ dramatically stimulated the hydrolysis of all $\alpha$-linked peptides tested but to extents that vary with the nature of the peptide substrate; thirdly, $\mathbf{M n}^{2+}$ stimulates the cleavage of only a few of the peptides tested and with these to a lesser extent than found with $\mathrm{Co}^{2+}$. The effect of $\mathrm{Mn}^{2+}$ upon the cleavage of peptides containing basic amino acids seems to be minimal; the greatest stimulation occurred with peptides that possess neutral residues only. Neither $\mathrm{Co}^{2+}$ nor $\mathrm{Mn}^{2+}$ stimulated cleavage of the $\beta$ - or $\gamma$-linked peptides tested.

\section{DISCUSSION}

While studying peptide transport in Escherichia coli we became interested in the growth of amino acid auxotrophs on peptides (Payne, 1971 $a, b$; Payne \& Gilvarg, 1971), and in the 
general role of peptidases in the bacterial utilization of peptides. The subject of the transport and utilization of peptides in bacteria has recently been reviewed (Sussman \& Gilvarg, 197I).

The peptidases of Escherichia coli appear to be truly intracellular and are neither released by osmotic shock (Van Lenten \& Simmonds, 1967) nor by sphaeroplast formation (Matheson \& Murayama, 1966; Simmonds \& Toye, 1966; Van Lenten \& Simmonds, 1967). Upon disruption of the organism these intracellular peptidases may be characterized further either as ribosomal (Dick, Matheson \& Wang, 1970), or soluble (Stone, 1953; Sarid et al. 1959, I962; Simmonds \& Toye, I966, I967; Haley, I968; Yaron \& Mlynar, I968; Simmonds, 1970 ; Vogt, 1970; Sussman \& Gilvarg, 1970, 1971). In this paper we have investigated only the soluble peptidases that are found in the supernatant extract after disruption of the bacteria; previous studies indicate this to be the major source of cellular peptidase activity (Simmonds, 1970). Although earlier studies have provided evidence for a number of peptidases of varied substrate specificities, and several of these enzymes have been purified and characterized, our aim here was to study the peptidase complement of the extract with a view to assessing the most active peptidases towards several dipeptides used as nutrients for amino acid auxotrophs (Payne, I $97 \mathrm{I} a, b$ ). It is presumed that the enzymes that display the greatest peptidase activity in vitro towards certain peptides are likely to be the peptidases that play the most important role in the utilization of these same peptides by cultures of auxotrophic bacteria. Three dipeptides were selected as being structurally rather dissimilar and likely therefore to be mainly cleaved by dipeptidases of differing substrate specificities. The characterization of such peptidases forms a necessary preliminary to studies of the variation of peptidase activity with growth conditions (Payne, 1972). The results suggest that the predominant hydrolytic activity towards all three dipeptides probably resides in a single $\mathrm{Co}^{2+}$ activated peptidase, although confirmation of this would require fractionation of the crude extract. The observations with the three dipeptides that suggest a low substrate specificity are reinforced by the further studies (Table 4) with the selection of dipeptides that contain a broad spectrum of amino acid types; in all cases $\mathrm{Co}^{2+}$ significantly stimulated hydrolysis. Several facts indicate that the $\mathrm{Mn}^{2+}$ activated hydrolysis derives from a distinct $\mathrm{Mn}^{2+}$ activated enzyme(s) rather than from an inferior activation by $\mathrm{Mn}^{2+}$ of the $\mathrm{Co}^{2+}$ enzyme(s); the most important of these are the following: first, the activity towards diglycine, when $\mathrm{Co}^{2+}$ ( $\mathrm{ImM}$ ) and $\mathrm{Mn}^{2+}$ ( $\mathrm{ImM}$ ) are present together, essentially equals the sum of the individual activities when they are tested separately (Table I); second, veronal buffer inhibits the $\mathrm{Co}^{2+}$ activated cleavage while permitting normal $\mathrm{Mn}^{2+}$ activated hydrolysis; and third, although phosphate enhances the $\mathrm{Co}^{2+}$ cleavage it is without specific effect on $\mathrm{Mn}^{2+}$ cleavage.

Comparison of the results here with those of other workers indicates that the $\mathrm{Co}^{2+}$ enzyme, which in our hands appears to be the most active peptidase in Escherichia coli, has yet to be purified and characterized. Sussman \& Gilvarg (1970) described a $\mathrm{Co}^{2+}$ activated dilysine peptidase from E. coli but this was only partially purified and its activity towards other substrates was not tested. Simmonds \& Toye (1967) showed that a peptidase present in the soluble portion of an extract of E. coli KI2 was activated by $\mathrm{Co}^{2+}$, but they did not make detailed studies of this activity and concentrated instead upon the $\mathrm{Mn}^{2+}$ activated peptidases (Simmonds \& Toye, 1966, 1967; Van Lenten \& Simmonds, 1967; Simmonds, 1970). Simmonds and her co-workers were studying a different strain of $E$. coli, although the peptidase complement of different strains of $E$. coli does appear to be very similar (see later and Sussman \& Gilvarg, 1970).

A number of $\mathrm{Mn}^{2+}$ activated peptidases have been reported in Escherichia coli extracts and several have been isolated (Stone, 1953; Sarid et al. 1962; Simmonds \& Toye, 1966, 
I967; Van Lenten \& Simmonds, I967; Yaron \& Mlynar, I968; Simmonds, I970; Vogt, 1970). It is likely that the $\mathrm{Mn}^{2+}$ activated hydrolysis described here resides in one or more of these enzymes; certainly, the results of the $\mathrm{Mn}^{2+}$ concentration studies (Fig. 2) and the substrate specificity results (Table 4 ) are consistent with the presence of several $\mathrm{Mn}^{2+}$ enzymes.

Further studies with veronal suggest that its inhibitory effect is not an artifact of the assay procedure, neither does it significantly sequester $\mathrm{Co}^{2+}$ ions, and it seems more likely to be affecting the enzyme itself. Veronal has often been used for assays of Escherichia coli peptidases (Sarid et al. 1959, 1962; Nishi \& Hirose, I966; Yaron \& Mlynar, 1968). In further studies therefore we compared the activities of both sonic extracts and toluene-treated organisms from batch-grown strains of $E$. coli B, KI2 and w towards diglycine, divaline and prolylglycine. In all cases, $\mathrm{Co}^{2+}$ greatly enhanced cleavage of the dipeptides, the activities were greatest in phosphate buffer, and low activities (about $10 \%$ ) were observed in veronal. In general therefore, veronal appears to be an unsuitable buffer, although it could be useful for assaying other peptidases, e.g. isolation of a specific proline iminopeptidase was probably facilitated by using veronal and therefore inhibiting hydrolysis of the substrate prolylglycine by the more active $\mathrm{Co}^{2+}$ peptidase (Sarid et al. 1959 ).

These results therefore provide an assessment of the effects of incubation conditions on the measurement of Escherichia coli peptidase activity, and indicate procedures for optimal expression of the major peptidase activities that are found in a crude extract. The fact that the $\mathrm{Co}^{2+}$ and $\mathrm{Mn}^{2+}$ activated enzymes retain about $90 \%$ of their activities towards all three dipeptides after storage at $-20^{\circ} \mathrm{C}$ for three months in phosphate $\mathrm{pH} 7$ (IO mM), should encourage further work on the isolation of the individual activities.

I am indebted to Mr J. R. Hunter for cultivation of bacteria. I thank Miss S. Stainer and Mr A. R. Blake for their skilled technical assistance.

\section{REFERENCES}

Binkley, F., LeIBACH, F. \& KING, N. (I968). A new method of peptidase assay and the separation of three leucylglycinases of renal tissues. Archives of Biochemistry and Biophysics 128, 397-405.

Dick, A. J., Matheson, A. T. \& WANG, J. H. (1970). A ribosomal bound amino peptidase in Escherichia coli $\mathrm{B}$ : purification and properties. Canadian Journal of Biochemistry 48, I I 8 I-I 188.

HaLey, E. E. (I968). Purification and properties of a $\beta$-aspartyl peptidase from Escherichia coli. Journal of Biological Chemistry 243, 5748-5752.

Kenny, A. J., WongLeung, Y. L. \& Ingram, J. (I968). Comparison of enzymes in rat kidney that hydrolyse L-leucinamide, L-leucyl-p-nitroanilide and iodinated insulin B chain. Biochemical Journal 1ro, 6P.

Kogoma, T. \& Nishi, A. (1965). Rhythmic variations in proteolytic activities during the cell cycle of Escherichia coli. Journal of General and Applied Microbiology I1, 32 I-329.

Matheson, A. T. \& Murayama, T. (I966). Limited release of ribosomal peptidase during formation of Escherichia coli spheroplasts. Canadian Journal of Biochemistry 44, I407-1415.

Michaelis, L. \& Schubert, M. P. (I930). Cobalt complexes of thioglycollic acid. Journal of the American Chemical Society 52, 44I 8-4426.

Nishi, A. \& Hirose, S. (I966). Further observations on the rhythmic variation of peptidase activity during the cell cycle of various strains of Escherichia coli. Journal of General and Applied Microbiology 12, $293-297$.

PAYNE, J. W. (I968). Oligopeptide transport in Escherichia coli: specificity with respect to side chain and distinction from dipeptide transport. Journal of Biological Chemistry 243, 3395-3403.

PAYNe, J. W. (I97I $a$ ). The requirement of the protonated $\alpha$-amino group for the transport of peptides in Escherichia coli. Biochemical Journal 123, 245-254.

Payne, J. W. (197 I $b$ ). The utilization of prolyl peptides by Escherichia coli. Biochemical Journal 123, 255-260.

PAYNE, J. W. (I972). Variations in the peptidase activities of Escherichia coli in response to environmental changes. Journal of General Microbiology 7r, 28I-29I.

Payne, J. W. \& Gilvarg, C. (1971). Peptide transport. Advances in Enzymology 35, I87-244. 
Sarid, S., Berger, A. \& Katchalski, E. (1959). Proline iminopeptidase I. Journal of Biological Chemistry 234, $1740-1746$.

Sarid, S., Berger, A. \& Katchalski, E. (1962). Proline iminopeptidase 2. Journal of Biological Chemistry 237, 2207-2212.

SIMmonds, S. (I970). Peptidase activity and peptide metabolism in Escherichia coli KI 2. Biochemistry 9, I-9.

Simmonds, S., Harris, J. I. \& Fruton, J. S. (195I). Inhibition of bacterial growth by leucine peptides. Journal of Biological Chemistry 188, $25 \mathrm{I}-262$.

Simmonds, S., TAtum, E. L. \& Fruton, J. S. (1947). The utilization of leucine derivatives by a mutant strain of Escherichia coli. Journal of Biological Chemistry 17o, 483-489.

Simmonds, S. \& Toye, N. O. (1966). Peptidases in spheroplasts of Escherichia coli Kı 2. Journal of Biological Chemistry, 241, 3852-3860.

Simmonds, S. \& Toye, N. O. (1967). The role of metal ions in the peptidase activity of Escherichia coli KI 2. Journal of Biological Chemistry 242, 2086-2093.

Smith, E. L. (195I). The specificity of certain peptidases. Advances in Enzymology 12, 19I-257.

STONE, D. (I953). Some aspects of the hydrolysis of proline peptides by a prolineless mutant of Escherichia coli. Journal of Biological Chemistry 202, $82 \mathrm{I}-827$.

Sussman, A. J. \& Gilvarg, C. (1970). Peptidases in Escherichia coli $\mathrm{K} 12$ capable of cleaving lysine homopeptides. Journal of Biological Chemistry 245, 65 I 8-6524.

Sussman, A. J. \& Gilvarg, C. (1971). Peptide transport and metabolism in bacteria. Annual Reviews of Biochemistry 40, 397-408.

VAN Lenten, E. J. \& Simmonds, S. (1967). Dipeptidases in spheroplasts and osmotically shocked cells prepared from Escherichia coli KI 2. Journal of Biological Chemistry 242, I439-I 444.

VOGT, V. M. (1970). Purification and properties of an aminopeptidase from Escherichia coli. Journal of Biological Chemistry 245, 4760-4769.

WAdE, H. E. \& Phillips, B. W. (I971). Automated determination of bacterial asparaginase and glutaminase. Analytical Biochemistry 44, I89-199.

Yaron, A. \& MLynar, D. (I968). Aminopeptidase P. Biochemical and Biophysical Research Communications 32, 658-663. 